\title{
Site-Specific and Sensory Neuron-Dependent Increases in Postsynaptic Glutamate Sensitivity Accompany Serotonin-Induced Long-Term Facilitation at Aplysia Sensorimotor Synapses
}

\author{
Hui Zhu, Fang Wu, and Samuel Schacher \\ Center for Neurobiology and Behavior, Columbia University College of Physicians and Surgeons, and New York State \\ Psychiatric Institute, 722 West 168th Street, New York, New York 10032
}

Long-term changes in the efficacy of Aplysia sensory neuron (SN) connections accompany behavioral training or applications with $5-\mathrm{HT}$. The changes evoked by training or $5-\mathrm{HT}$ include formation of new SN varicosities and transmitter release sites. Because new synapse formation requires proper alignment of presynaptic structures with postsynaptic zones containing a high density of transmitter receptors, we examined whether changes in postsynaptic sensitivity to the presumed $\mathrm{SN}$ transmitter (glutamate) were correlated with formation and distribution of new SN varicosities in contact with motor cell L7 in cell culture. The formation of stable SN connections after $4 \mathrm{~d}$ in culture did not significantly change overall responses to focal applications of glutamate. However, specific sites along L7's axon apposed to SN varicosities expressed larger responses to glutamate compared with adjacent sites with few SN varicosi- ties. After treatments with 5-HT that evoked long-term changes in both the structure and the function of $\mathrm{SN}-\mathrm{L} 7$ synaptic interaction, glutamate responses increased selectively at sites along the surface of L7's axon with preexisting or new SN varicosities. Increases in postsynaptic response to glutamate $24 \mathrm{hr}$ after 5 - HT treatment required interaction with an $\mathrm{SN}$. These results suggest that new synapse formation between neurons, either with regeneration or after external stimuli that evoke increases in synaptic efficacy, involves site-specific changes in expression of functional neurotransmitter receptors on the postsynaptic cell that is regulated by interaction with the presynaptic neuron.

Key words: synapse formation; synapse plasticity; glutamate sensitivity; long-term; serotonin; Aplysia; cell culture
The formation of new synaptic connections requires the proper alignment of presynaptic structures with patches of postsynaptic membrane containing a high density of transmitter receptors. During development of the neuromuscular junction, interactions between the motor neuron and muscle influence both level of synthesis and focal concentration of postsynaptic neurotransmitter receptors (Jessell et al., 1979; Falls et al., 1990; McMahan, 1990; Broadie and Bate, 1993a,b,c; Hall and Sanes, 1993). Although receptors on central neurons in the spinal cord and hippocampus appear to form patches of high density at sites contacted by presynaptic structures that are likely to be transmitter release sites (O'Brien and Fischbach, 1986a,b; Bekkers and Stevens, 1989; Craig et al., 1993, 1994; Liu and Tsien, 1995; Vogt et al., 1995; Ehlers et al., 1996), the mechanisms that direct the aggregation of different transmitter receptors to specific postsynaptic zones during synapse formation are not known. In addition, mechanisms underlying possible changes in distribution of receptors on neurons in the mature nervous system that may contribute to activity-dependent long-term changes in synaptic efficacy are not known (Lynch and Baudry, 1984; Davies et al., 1989;

Received Jan. 16, 1997; revised April 10, 1997; accepted April 16, 1997.

This research was supported by National Institutes of Health Grants GM 32099 and NS 27541. We thank Robert Woolley, Eve Vagg, and Rachel Yarmolinsky for assistance in preparing the figures, and Drs. I. Kupfermann, L. Role, Z.-Y. Sun, and R. Silverman for comments on earlier drafts of this manuscript. Animals were provided by the National Center for Research Resources for Aplysia at the University of Miami under National Institutes of Health Grant RR 10294.

Correspondence should be addressed to Dr. Samuel Schacher, Center for Neurobiology and Behavior, Columbia University College of Physicians and Surgeons, New York State Psychiatric Institute, 722 West 168th Street, New York, NY 10032.

Copyright (C) 1997 Society for Neuroscience 0270-6474/97/174976-11\$05.00/0
Bailey and Kandel, 1993; Maren et al., 1993; Isaac et al., 1995; Edwards, 1995).

Previous studies of identified neurons of Aplysia in culture indicated that a number of changes in the presynaptic neuron are correlated with interaction and synapse formation with appropriate postsynaptic targets. These changes are apparent during regeneration of new synaptic connections (Glanzman et al., 1989a; Hawver and Schacher, 1993) and with structural plasticity evoked by 5-HT (Glanzman et al., 1990; Glanzman, 1995) or by FMRFamide (Schacher and Montarolo, 1991). These two neurotransmitters evoke long-term plasticity of stable sensory neuron ( $\mathrm{SN}$ ) synaptic connections that correlate with cellular changes that accompany long-term behavioral plasticity in Aplysia (Castellucci et al., 1978; Bailey and Chen, 1983, 1988a,b; Frost et al., 1985). Interactions with the target motor cell L7 induce alteration in neuritic branches and the number of SN varicosities with active zones for transmitter release, increased expression of neuropeptide in varicosities contacting the target, and alterations in the distribution of functional receptors for 5-HT and FMRFamide (Glanzman et al., 1989a, 1990; Schacher and Montarolo, 1991; Zhu et al., 1994; Santarelli et al., 1996; Sun and Schacher, 1996).

Does interaction with an SN affect the distribution of transmitter receptors on the surface of L7? Recent studies (Dale and Kandel, 1993; Trudeau and Castellucci, 1993; Lin and Glanzman, 1994; Gapon and Kupfermann, 1996) suggest that most SNs in Aplysia use amino acids to evoke fast excitatory responses in follower cells. The distribution of receptors on postsynaptic targets of SNs may contribute to changes in synaptic function. Trudeau and Castellucci (1995) reported that 
chronic treatment of the abdominal ganglion with 5-HT that evoked modest long-term facilitation of SN-L7 connections also produced an overall increase in sensitivity on L7 to exogenous applications of homocysteic acid.

To begin to explore how presynaptic neurons might influence changes in the postsynaptic cell that contribute to new synapse formation, we used SN-L7 cultures to correlate postsynaptic responses to focal applications of glutamate with the presence of presynaptic varicosities. We then tested whether changes in glutamate responses are correlated with the local structural properties of the presynaptic SN after treatments with 5-HT that evoke long-term changes in the structure and function of SN-L7 connections (Montarolo et al., 1986; Glanzman et al., 1990). We found that glutamate evoked larger responses at sites along L7's axon with SN varicosities, compared with adjacent sites, with few varicosities. After 5-HT applications that evoked long-term facilitation, responses to glutamate increased significantly only at postsynaptic sites contacted by preexisting and new $\mathrm{SN}$ varicosities. In the absence of an $\mathrm{SN}$, no significant change in glutamate sensitivity was observed 24 hr after 5-HT treatment. These results suggest that new synapse formation between central neurons of Aplysia is accompanied by changes in the expression of functional neurotransmitter receptors on the postsynaptic cell that is regulated by specific interactions with the presynaptic neuron.

\section{MATERIALS AND METHODS}

Cell culture. Mechanosensory neurons of Aplysia were isolated from the pleural ganglion dissected from adult animals (70-100 gm), co-cultured with identified motor cell L7 isolated from the abdominal ganglion of juvenile animals (1-3 gm) (University of Miami Aplysia Mariculture Facility) and maintained for up to $5 \mathrm{~d}$ as described previously (Schacher and Proshansky, 1983; Schacher, 1985; Rayport and Schacher, 1986). Individual motor cells were isolated with long segments $(400-750 \mu \mathrm{m})$ of their original axons (Schacher and Proshansky, 1983). Each culture contained either a single sensory cell co-cultured with a single L7 or a L7 cultured alone. In some cultures, two motor cells were plated, and an SN was allowed to form synaptic contacts with one of them. Cultures were allowed to regenerate for $4 \mathrm{~d}$ to permit the establishment of stable synaptic contacts and neuritic arbors (Montarolo et al., 1986; Glanzman et al., 1990; Schacher and Montarolo, 1991).

Electrophysiology. The stimulation and recording techniques for measuring changes in the efficacy of the SN-L7 connection have been described (Montarolo et al., 1986; Wu et al., 1995). For monitoring changes in synaptic efficacy or glutamate sensitivity, the motor cell was impaled with a microelectrode (10-15 M $)$ ) containing $2.0 \mathrm{M} \mathrm{K}$-acetate, $0.5 \mathrm{M} \mathrm{KCl}$, $10 \mathrm{~mm}$ K-HEPES, $\mathrm{pH}$ 7.4. The motor cell L7 was maintained at approximately $-70 \mathrm{mV}$ for measuring both the EPSP and responses to brief focal applications of glutamate (see below). For each co-culture, synaptic potentials were evoked in $\mathrm{L} 7$ by stimulating the $\mathrm{SN}$ with a single brief (50 $\mathrm{msec}$ ) depolarization using the dye-filled intracellular electrode after the iontophoretic injection of the dye (see below). During the recording and dye-filling, cultures were superfused at $1 \mathrm{ml} / \mathrm{min}$ with L15-seawater medium consisting of artificial seawater (Instant Ocean) and modified L15 with salt concentrations added to levels consistent with seawater. After imaging the SN-L7 interaction and applying glutamate (see below), 5-HT was bath-applied (final concentration, $2 \mu \mathrm{M}$ ) four times at $25 \mathrm{~min}$ intervals. Each application lasted 5 min (Montarolo et al., 1986). During the interval between applications of 5-HT, cultures were rinsed with L15-seawater at $1 \mathrm{ml} / \mathrm{min}$. The same cultures were reexamined $24 \mathrm{hr}$ later.

Dye injection and imaging structural changes. The fluorescent dye 5(6)-carboxyfluorescein (Molecular Probes, Eugene, OR; 6\% in $0.44 \mathrm{M}$ $\mathrm{KOH}, \mathrm{pH}=7.0$ ) was injected into SNs with $0.3-0.5 \mathrm{nA}$ hyperpolarizing current pulses $(500 \mathrm{msec}$ at $1 \mathrm{~Hz})$ for 5-6 min (Glanzman et al., 1989a; Schacher and Montarolo, 1991). Nomarski or phase contrast and fluorescent images of the same view areas along the axons of L7 were taken to map out the location of $\mathrm{SN}$ varicosities and neurites at each time point (days 4 and 5) and to identify zones for repeated focal applications of glutamate (see below). Images were taken with a Nikon Diaphot microscope attached to a SIT (Dage 68) video camera, processed by a Dell 310 computer with a PC Vision Plus frame grabber, and subsequently stored on a Panasonic optical disk drive. Alignment of the live view area at the second time point with the initial recorded image was aided by the computer, with fine adjustments made with the stage controls, and by manual rotation of the culture dish. Illumination used for obtaining fluorescent images was kept as low as possible to prevent photodamage. To minimize differences in imaged structures that might arise as a result of differences in the extent of dye-filling, light intensities used at the second time point were adjusted to match the intensity of the stored images taken before treatment.

Quantifying structural changes. Counts of varicosity number were obtained from fluorescent images of SN neurites contacting the proximal 350-400 $\mu \mathrm{m}$ of L7's axon. Previous studies had indicated that this portion of L7's axon is the most favorable substrate for growth of SN neurites that form varicosities with transmitter release sites (Glanzman et al., 1989a, 1990; Schacher et al., 1990). SN varicosities can be found at any position along this proximal portion of L7's axon (Bank and Schacher, 1992). Because the axon of L7 is a relatively thick structure, it often required as many as four different focal planes to image all of the labeled neurites and varicosities in a given view area. To minimize slight differences in focus that could obscure differences in varicosity number, we used computer-assisted superimposition of the various focal planes onto a single two-dimensional image. The matched fluorescent images of each focal plane along with the superimpositions for both time points were compared and the total number of varicosities counted. A varicosity (swelling along a sensory cell process $>2 \mu \mathrm{m}$ in diameter) was considered new if the structure was not located within a $2 \mu \mathrm{m}$ radius in the same region of the motor axon on an earlier image of the area. Structures that were slightly elongated spheres $\geq 2 \mu \mathrm{m}$ connected by narrow neuritic necks were counted as varicosities (Bailey and Chen, 1983, 1988a). Counts of varicosities were performed blind; the individual did not know the amplitude of the EPSPs before or after treatment or the nature of the treatment. Only net change in varicosity number (not changes in varicosity shape) was used to measure structural changes evoked with treatments.

Focal applications of glutamate. Glutamate $(250$ or $1000 \mu \mathrm{M})$ was applied for $100 \mathrm{msec}$ by pressure ejection (10 psi) via micropipettes containing glutamate in L15-seawater with $0.02 \%$ fast green to visualize the location of the stream (Sun et al., 1996). The glutamate pipette was positioned near the midpoint of the substrate and the top surface of L7's axon (diameter, 20-30 $\mu \mathrm{m}$ ) and 3-5 $\mu \mathrm{m}$ from the surface membrane of L7. We used pipettes that ejected detectable levels of dye with steady application of $0.4-0.5$ psi of pressure. Without pressure, no detectable change in L7's membrane potential was recorded when the glutamate pipette was in position near a site along the axon. A second micropipette attached to a vacuum was positioned near the ejection pipette for rapid removal of glutamate (Fig. 1). The width of the stream across the surface of L7 was controlled by relative placement of the second pipette attached to the vacuum and the strength of the vacuum. Little or no desensitization in the response was detected with five repeated applications to the same site at $30 \mathrm{sec}$ intervals (with $40-\mu \mathrm{m}$ wide streams of $250 \mu \mathrm{M}$ glutamate) or $60 \mathrm{sec}$ intervals (with 10- to $15-\mu \mathrm{m}$-wide streams of $1000 \mu \mathrm{M}$ glutamate). Responses evoked at the same sites to local applications of glutamate $(1000 \mu \mathrm{M}$ with 10 - to 15 - $\mu \mathrm{m}$-wide steam) before, during $(1 \mathrm{~min})$, and after $(5 \mathrm{~min})$ a brief bath application of 5-HT that evokes short-term facilitation were not significantly different ( $n=4 \mathrm{SN}-\mathrm{L} 7$ cultures).

For measuring local responses to glutamate in $4 \mathrm{~d}$ cultures of $\mathrm{SN}-\mathrm{L} 7$ and L7 alone in the same dish, we first applied glutamate for $100 \mathrm{msec}$ to $40-\mu \mathrm{m}$-wide zones along the axon of each L7 centered at 100, 200, 300, 400 , and $500 \mu \mathrm{m}$ from the L7 cell body. A single application was applied to each zone at $\sim 2 \mathrm{~min}$ intervals. The order of application (proximal to distal site or distal to proximal site) did not affect the overall trend in the response. We then injected dye into the $\mathrm{SN}$ to identify adjacent sites along the L7 axon that contained significant differences in the number of $\mathrm{SN}$ varicosities. A second set of micropipettes, with properties comparable to the first set, was used to monitor responses evoked by a single $40-\mu \mathrm{m}$-wide application of glutamate to each site (at $\sim 2 \mathrm{~min}$ intervals). The order of application did not affect the average difference detected in the responses (glutamate applied first to zone with few varicosities in 4 of 7 cultures).

We also used micropipettes with comparable properties to determine changes in response after control or 5-HT treatments. Before recording 

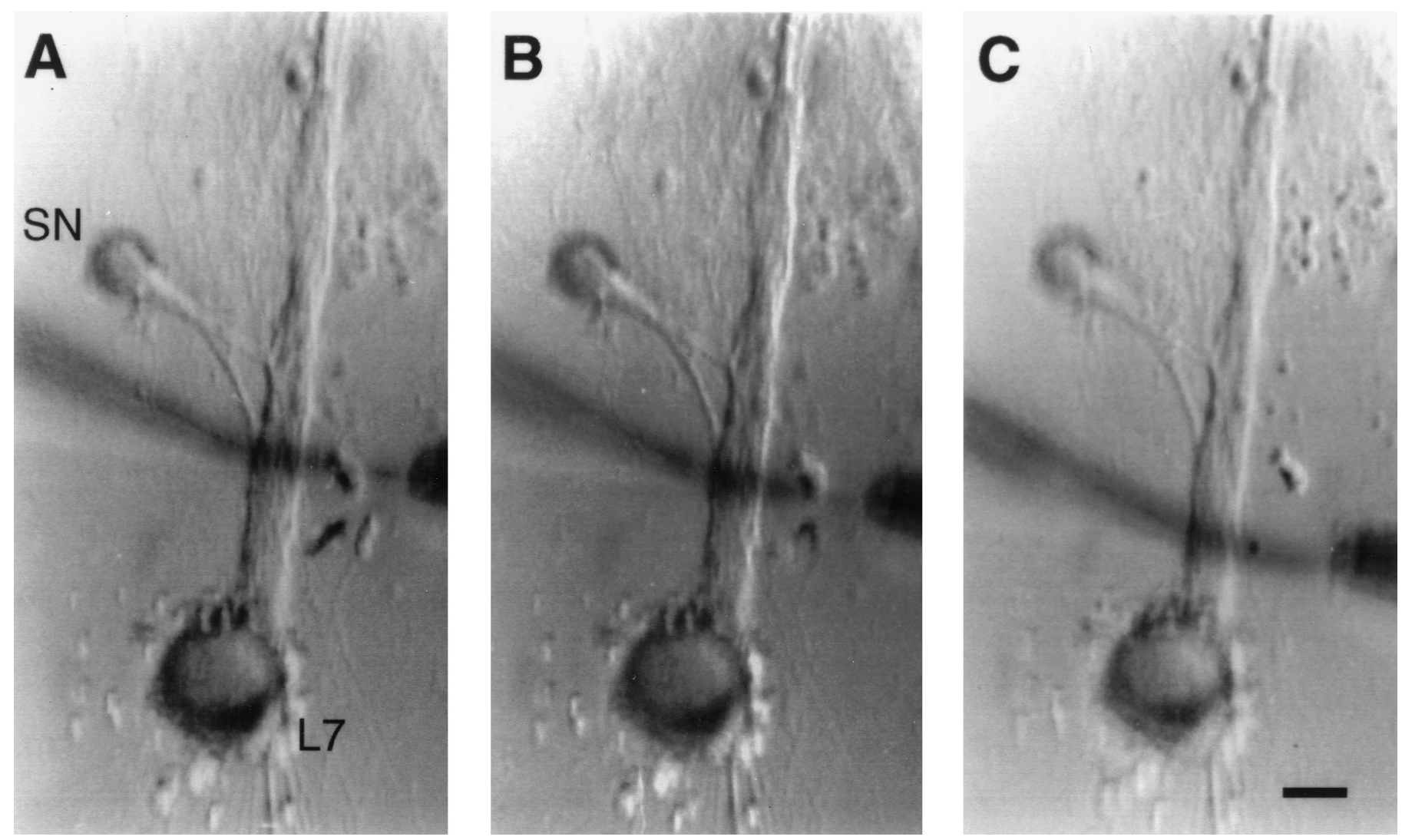

Figure 1. Focal applications of glutamate to adjacent nonoverlapping regions along the axon of L7. Low-power Nomarski contrast images of an SN-L7 culture after $4 \mathrm{~d}$. The axon of L7 emerges from the cell body and extends toward the top of each micrograph. The axon of the SN (left of motor axon) emerges from the cell body and extends toward the motor axon. The location of regenerated SN neurites and varicosities contacting L7's axon is determined with epifluorescent microscopy after intracellular dye injections (see Figs. 3-5). Micropipettes for pressure ejection (positioned at left of motor axon) and rapid suction (right of motor axon) of glutamate are placed opposite a given region at three locations along L7's axon (distal locations in $A$ and $B$ and most proximal location in $C$ ). The width of the glutamate stream is controlled by the placement of the electrodes and the strength of the vacuum. In these examples, the stream width is $\sim 10 \mu \mathrm{m}$. Scale bar, $40 \mu \mathrm{m}$.

on day 4 , cultures were assigned either to control or to 5-HT treatment group in an alternate manner. We selected seven nonoverlapping $10-15 \mu \mathrm{m}$ zones at $\sim 50 \mu \mathrm{m}$ intervals for monitoring glutamate responses over the proximal $400 \mu \mathrm{m}$ of L7's axon in the absence of an SN. Because SN varicosities can form at any site along this region of the motor axon (Bank and Schacher, 1992), it was difficult to select enough sites in the SN-L7 cultures that had regions with no varicosities. We therefore divided the seven nonoverlapping 10-15 $\mu \mathrm{m}$ zones along the proximal $400 \mu \mathrm{m}$ of L7's axon into two groups; one group had few SN varicosities $(\leq 2)$ and the other group of zones had at least three to as many as seven varicosities. The first zone in all $\mathrm{SN}-\mathrm{L} 7$ cultures was located at the most distal site with no varicosities and few, if any, SN neurites to determine whether treatment altered glutamate responses at sites with little SN interaction. Glutamate was applied for $100 \mathrm{msec}$ to each $10-15 \mu \mathrm{m}$ zone once at $\sim 2 \mathrm{~min}$ intervals both before and $24 \mathrm{hr}$ after control or 5-HT applications. Identification of the zones at the second time point was facilitated by Nomarski contrast images of the generally unchanging distribution of the distal neurites of L7 that extend along the substrate near the motor axon. The experimenter recording responses at the second application was unaware of the treatment given to the culture or of possible changes in structure of the fluorescent SN neurites and varicosities. Significant changes were determined via $t$ test or ANOVA, followed by Scheffe $F$ test to determine significance of differences between treatment groups.

\section{RESULTS}

\section{Local glutamate sensitivity is enhanced by the presence of SN varicosities}

Previous studies indicate that SN varicosities in contact with the motor axon are the primary sites of synaptic interaction.
The number of SN varicosities apposed to L7's axon correlates with the efficacy of the synapse as the connections between the cells are established and stabilized during the first $4 \mathrm{~d}$ in culture (Glanzman et al., 1989a, 1990; Schacher and Montarolo, 1991; Sun and Schacher, 1996). Stable SN synapses can undergo long-term changes in synaptic efficacy after treatments with 5-HT or FMRFamide that are accompanied by changes in the number of SN varicosities contacting the motor axon (Glanzman et al., 1990; Schacher and Montarolo, 1991). SN varicosities in contact with the axon of L7, either those that form after $4 \mathrm{~d}$ in culture or those that form after treatments with 5-HT evoking long-term facilitation, contain transmitter release sites (Glanzman et al., 1989a, 1990; Schacher et al., 1990). We therefore examined whether the presence of SN varicosities was correlated with the amplitude of the response in L7 to focal applications of glutamate along the surface of L7's axon. We compared responses evoked by glutamate in cultures with two L7 cells, where only one L7 per culture was contacted by an SN and formed synaptic connections.

For both types of cultures, L7 alone or SN-L7 co-culture, responses to focal applications of glutamate (100 $\mathrm{msec}$ of 250 $\mu \mathrm{M}$ ) declined at more distal zones along the L7 axon (Fig. 2). Maximal response to glutamate was obtained with $40-\mu \mathrm{m}$-wide applications along L7's axon centered at $100 \mu \mathrm{m}$ from the cell body and declined by $\sim 50 \%$ with applications centered at 300 

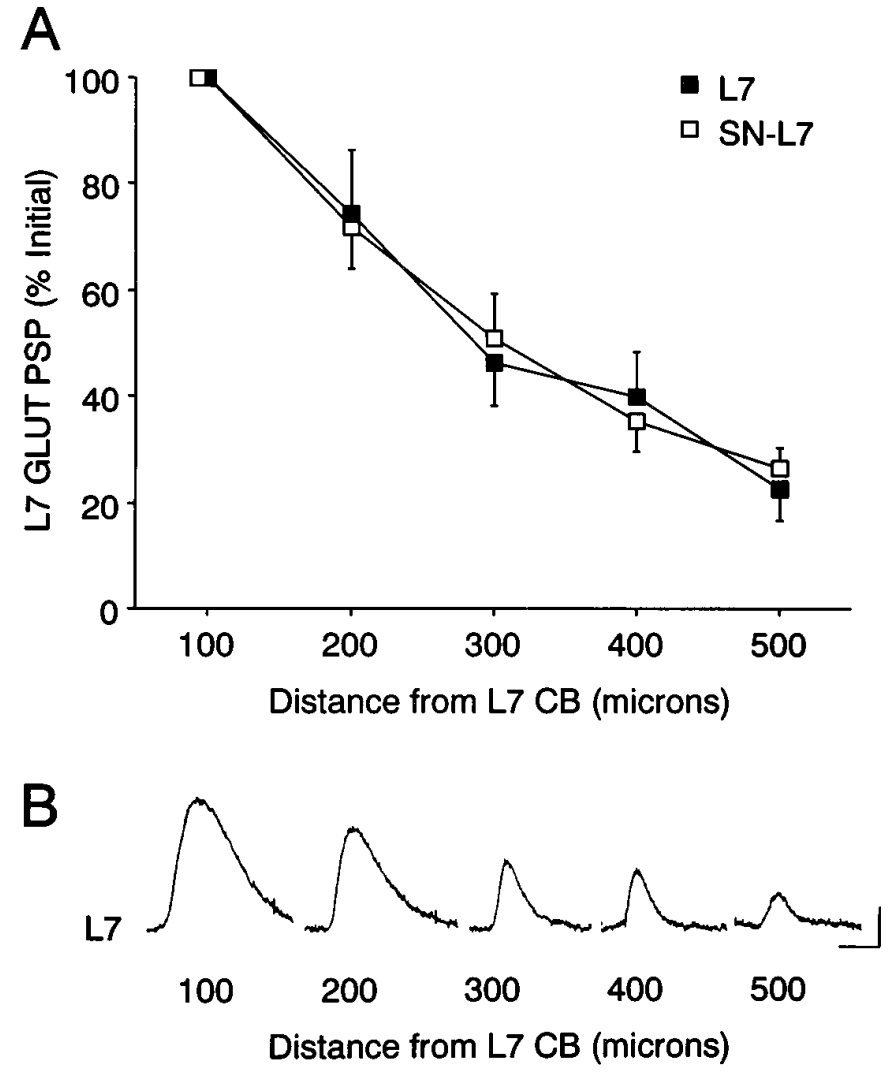

Figure 2. Glutamate response declines at more distal zones along the L7 axon, irrespective of interaction with an SN. $A$, Maximal response to glutamate is obtained with applications at $100 \mu \mathrm{m}$ from the L7 cell body (normalized as $100 \%$ for each L7; $n=7$ for each condition). A $40-\mu \mathrm{m}-$ wide stream of $250 \mu \mathrm{M}$ glutamate centered at the indicated distance along the axon was used to evoke each response for each type of culture. The same set of micropipettes (one to eject glutamate and the other to rapidly remove transmitter) was used to record responses from both L7s in each culture dish. Note that the average response declines by $\sim 50 \%$ at $300 \mu \mathrm{m}$ from the L7 cell body. A two-factor ANOVA indicated that although there was a significant decline in response with distance from the L7 cell body $(p<0.001)$, there was no difference in the responses between L7 cultured alone and SN-L7 co-cultures ( $\mathrm{df}=4,48 ; F=0.385 ; p>0.8)$. $B$, Example of a series of responses to glutamate applied to the locations indicated from the L7 cell body for a motor cell cultured alone. Calibration: vertical, $2 \mathrm{mV}$; horizontal, $200 \mathrm{msec}$.

$\mu \mathrm{m}$ from the cell body ( $n=7$ for each type of culture). Glutamate applied $<100 \mu \mathrm{m}$ from the cell body also evoked weaker responses (average $\sim 60 \%$ of the maximum; for examples, see Figs. 4 and 6). The change in the amplitude of the response with distance from the recording site may reflect electrotonic decay of the response and/or differences in the expression of functional receptors. In addition, the overall amplitude of the glutamate responses (as measured by the average sum of the five responses per L7) was not altered by the presence of an SN that had formed connections with L7; $27.9 \pm 4.4 \mathrm{mV}$ per $\mathrm{L} 7$ maintained alone versus $32.3 \pm 1.1 \mathrm{mV}$ per L7 for the co-cultures. However, significant differences in response were obtained for adjacent zones in the co-cultures that correlated with the presence and absence of SN varicosities (Fig. 3). We selected areas that were $\sim 300 \mu \mathrm{m}$ (range, $250-400 \mu \mathrm{m}$ ) from the L7 cell body in the SN-L7 co-cultures. Application of glutamate to a $40-\mu \mathrm{m}$-wide zone along the axon of L7 with more SN varicosities (2.5- to 5-fold more) evoked a response that was on average $\sim 2$.7-fold greater than responses of adjacent and more proximal $40-\mu \mathrm{m}$-wide zones of the L7 axon that contained few $\mathrm{SN}$ varicosities (Fig. $3 A, B$ ). Thus, glutamate sensitivity is upregulated at sites where SNs typically form synaptic contacts with L7.

\section{Long-term facilitation of SN-L7 synapses is accompanied by increase in glutamate sensitivity primarily at zones with preexisting and new SN varicosities}

Repeated brief applications of 5-HT evoke long-term facilitation in the efficacy of Aplysia SN synaptic connections both in cell culture (Montarolo et al., 1986) and in the intact ganglion (Clark and Kandel, 1993; Emptage and Carew, 1993). The change in synaptic efficacy is accompanied by the formation of new SN varicosities with transmitter release sites (Glanzman et al., 1990; Schacher et al., 1990; Zhu et al., 1995; Santarelli et al., 1996). To test whether there were corresponding changes in glutamate sensitivity on the postsynaptic L7, we compared postsynaptic responses to focal applications of glutamate after visualizing the SN-L7 interactions with intracellular dye injections both before and $24 \mathrm{hr}$ after repeated applications of 5-HT.

As reported previously, $4 \times$ applications of 5-HT evoked a significant increase in both the amplitude of the EPSP and the number of $\mathrm{SN}$ varicosities in contact with the proximal portion of L7's axon when the same cultures were reexamined $24 \mathrm{hr}$ later (for summary, see Fig. $8 A, B$ ). Whereas repeated applications of control solutions evoked a change of $2.2 \pm 4.1 \%$ in EPSP amplitude ( $n=10$ cultures), 5-HT applications evoked a significant change of $40.5 \pm 5.3 \%$ ( $n=10$ cultures). The net change in the number of $\mathrm{SN}$ varicosities per culture was $0.9 \pm 1.1$ in controls versus $7.4 \pm 1.9$ for cells treated with 5 -HT.

The responses evoked by 10 - to $15-\mu \mathrm{m}$-wide applications of glutamate were enhanced after treatment with 5-HT, especially at sites along the motor cell axon that were contacted by $\mathrm{SN}$ varicosities (Figs. 4, 5). Before treatment, the average amplitude and rate of rise of the glutamate responses were comparable for both groups. The average response per zone per culture before 5-HT treatment was not significantly different $(p>0.2)$ from the average response for control cultures; $5.6 \pm$ $1.0 \mathrm{mV}$ and a rate of rise of $58 \pm 9.6 \mathrm{mV} / \mathrm{sec}$ for the $5-\mathrm{HT}$ group compared with $6.2 \pm 0.8 \mathrm{mV}$ and a rise time of $69 \pm 7.2$ $\mathrm{mV} / \mathrm{sec}$ for controls. Glutamate applications to zones with more than two varicosities (Fig. 4, zones 3-5) evoked larger responses after 5-HT treatment relative to the responses evoked in the other postsynaptic zones, which contained few $\mathrm{SN}$ varicosities. Large increases in sensitivity $(>50 \%)$ were generally accompanied by significant increases in the rate of rise of the responses. By contrast, little change in the amplitude of the glutamate response was found in control cultures at most sites along the motor axon. On the few occasions when a large $(>25 \%)$ increase was observed, the change in glutamate response correlated with a structural change involving an increase in the number of SN varicosities (for example, Fig. 5, zone 5). Overall, the response to glutamate in the co-cultures treated with 5 -HT increased by $53.2 \pm 12.2 \%$ per culture, which was significantly greater than the overall change of $2.8 \pm$ $7.5 \%$ in control cultures (see Fig. $8 C$ ). In parallel, there was an overall increase in the rate of rise of $82.5 \pm 13.5 \%$ per response per culture after treatment with 5-HT compared with an in- 


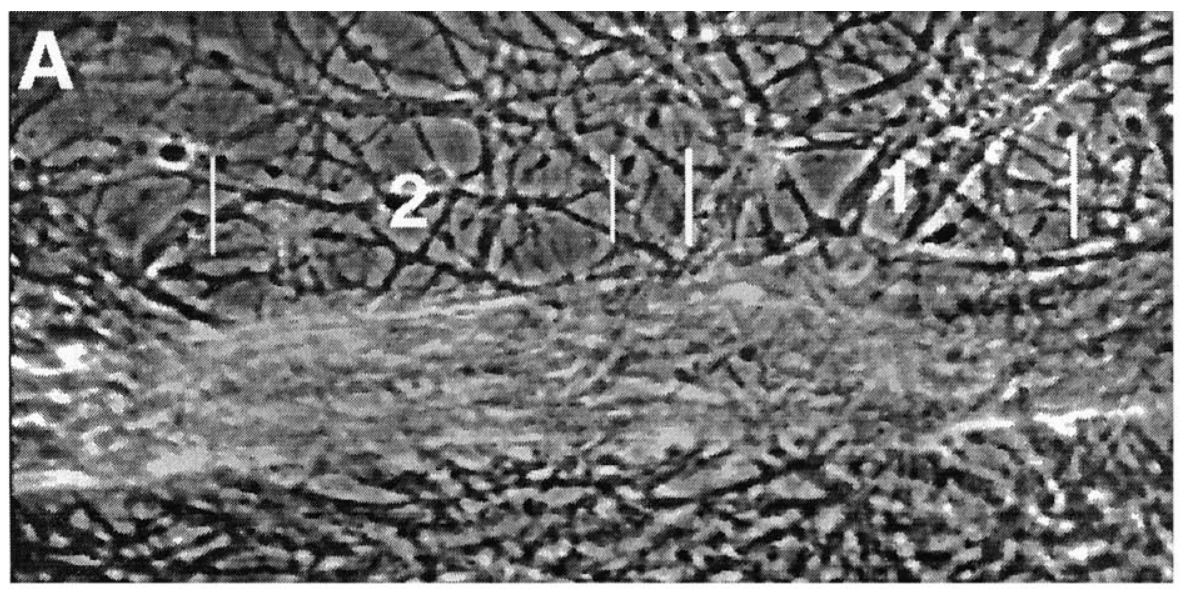

Figure 3. Local glutamate response is enhanced by the presence of SN varicosities. $A$, Phase-contrast micrograph of portion of L7 axon 250-400 $\mu \mathrm{m}$ from the L7 cell body (located to the left of this region). Zone 2 is closer to the L7 cell body. B, Epifluorescent view of $\mathrm{SN}$ neurites and varicosities in the same region as in $A$. Note that the more distal zone 1 has more $\mathrm{SN}$ varicosities in contact with L7's axon (10 varicosities) than $\mathrm{SN}$ varicosities in contact with the more proximal portion of the axon in zone 2 (two varicosities). Scale bar, $15 \mu \mathrm{m}$. $C$, Response to glutamate $(250 \mu \mathrm{M}$ for $100 \mathrm{msec})$ applied to zones 1 and 2, respectively. Calibration: vertical, $2 \mathrm{mV}$; horizontal, $200 \mathrm{msec}$. $D$, Summary of the differential responses evoked by glutamate to adjacent zones along L7's axon, where one zone has from 2.5- to 5-fold more SN varicosities. On average $(n=7$ cultures), there is a 2.7 -fold difference in gluta-

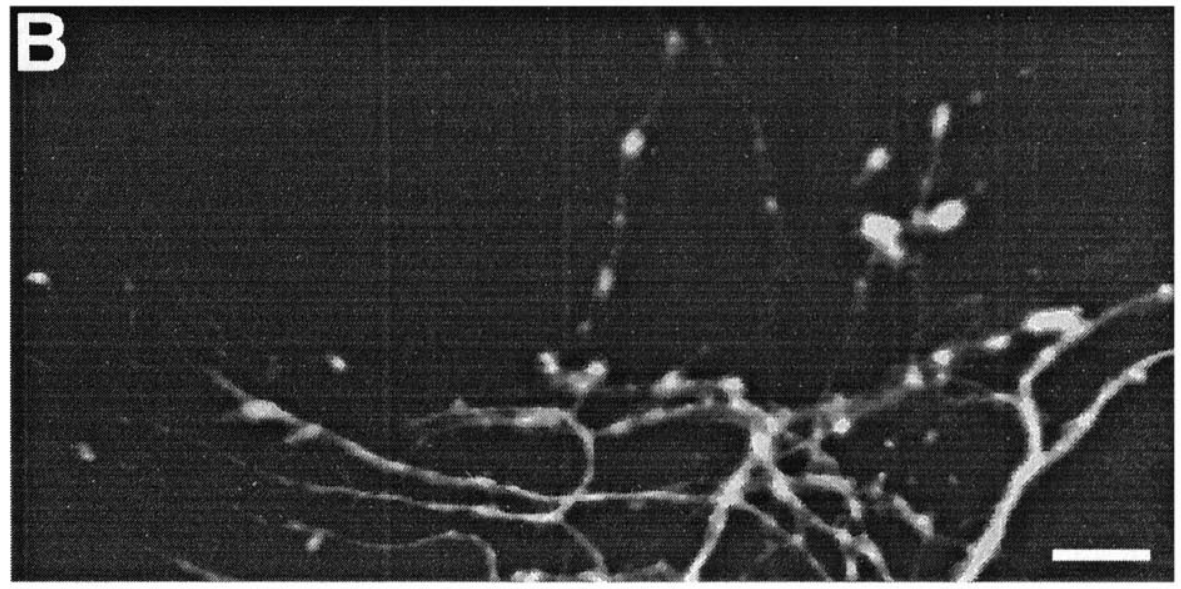

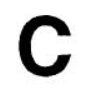
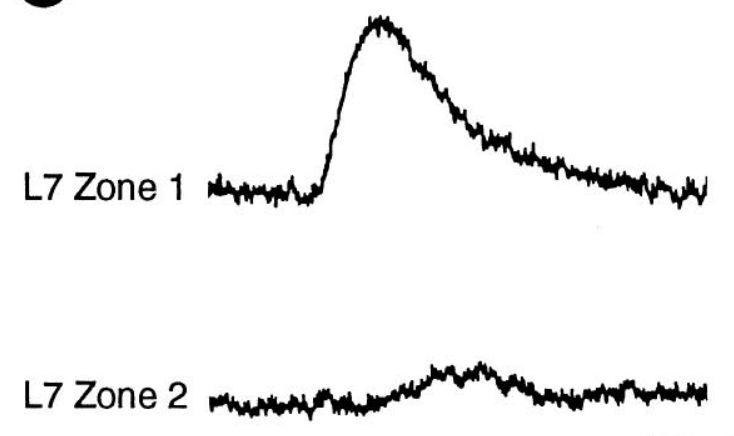
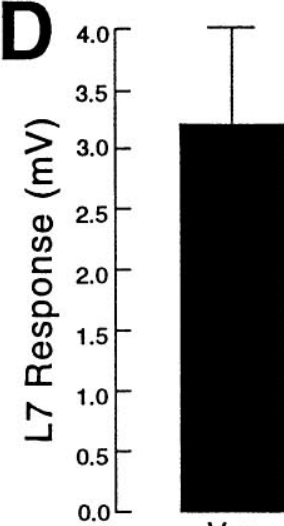

Var (zone 1)

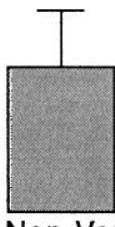

Non-Var

(zone 2) crease of $3.8+5.1 \%(p<0.01)$ for controls. The change in amplitude evoked by 5-HT was greater, however, at sites containing SN varicosities. The amplitude of the responses evoked by glutamate increased by $102.2 \pm 17.8 \%$ per culture at sites with three or more $\mathrm{SN}$ varicosities and was significantly greater than the change of $13.1 \pm 7.2 \%$ at sites along the same L7 axons with fewer $\mathrm{SN}$ varicosities. In control cultures, changes in the amplitude of the glutamate responses at sites with more SN varicosities were not significantly different from changes at sites along L7's axon with few SN varicosities; $6.8 \pm 8.9 \%$ compared with $0.3 \pm 6.9 \%$, respectively (see Fig. $8 D$ ). Thus, treatment with 5-HT evokes site-specific increases in glutamate responses that correspond to areas contacted by $\mathrm{SN}$ varicosities at the second time point.

\section{Long-term change in glutamate sensitivity with $5-\mathrm{HT}$ is dependent on the presence of an SN}

Next, we examined whether the change in glutamate response on the postsynaptic motor cell L7 that was evoked by 5-HT required the presence of the $\mathrm{SN}$ or whether it could be evoked by 5 -HT binding to receptors expressed on L7 alone. Regardless of the presence of an SN, L7 expresses receptors to 5-HT. At a holding potential of $-60 \mathrm{mV}$, bath application of 1-5 $\mu \mathrm{M}$ 5-HT evoked a hyperpolarization of $\sim 6 \mathrm{mV}$ (range, 4-9 $\mathrm{mV}$ ) in L7 that reversed rapidly at washout of the neuromodulator (data not shown). We compared the response to glutamate to the same zones along the surface of the motor cell before and $24 \mathrm{hr}$ after repeated applications of 5-HT (Fig. 6) or control 

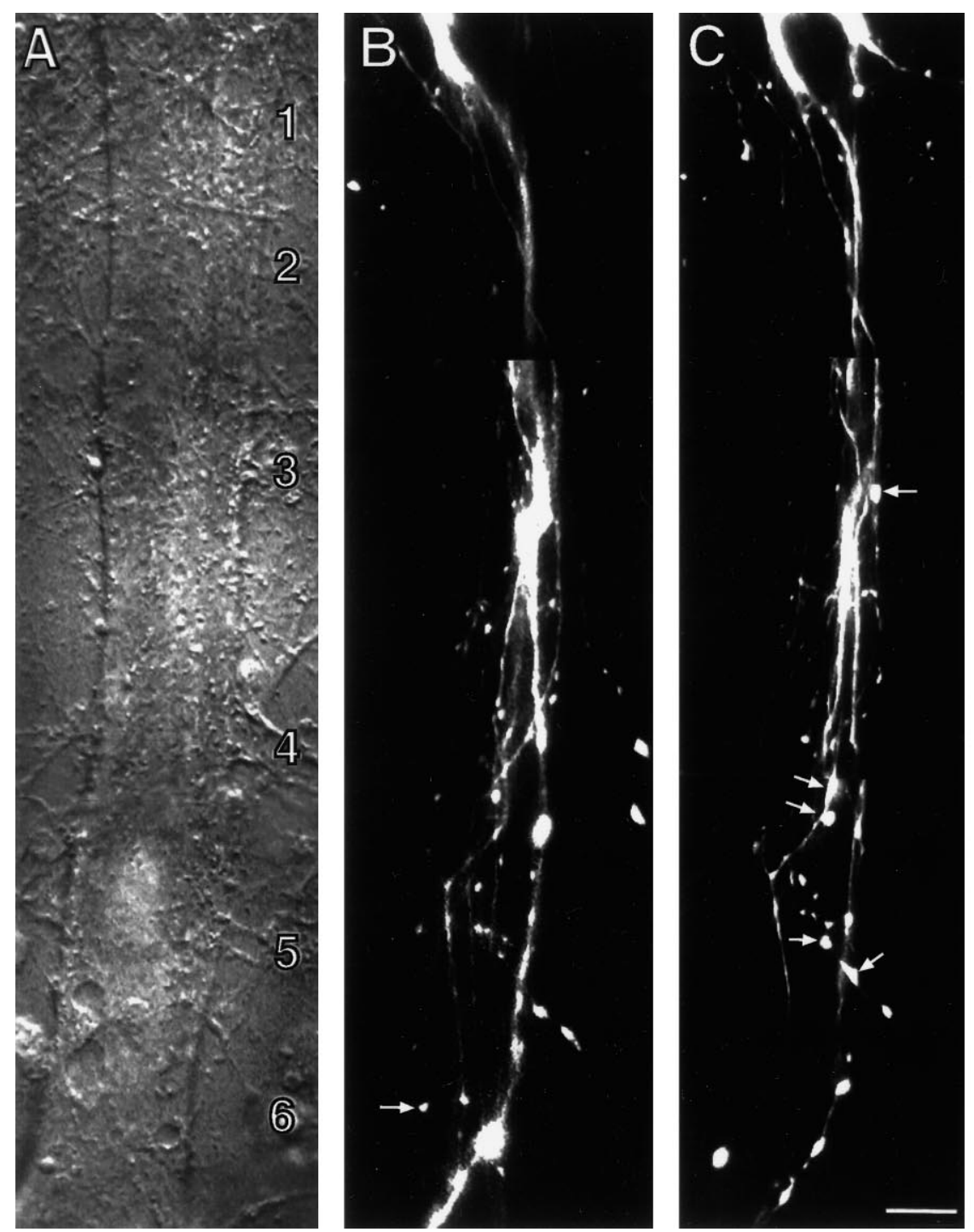

D

1

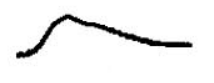

2
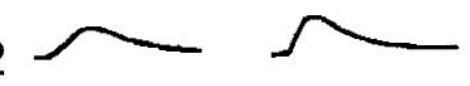

3
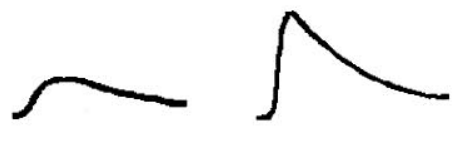

4
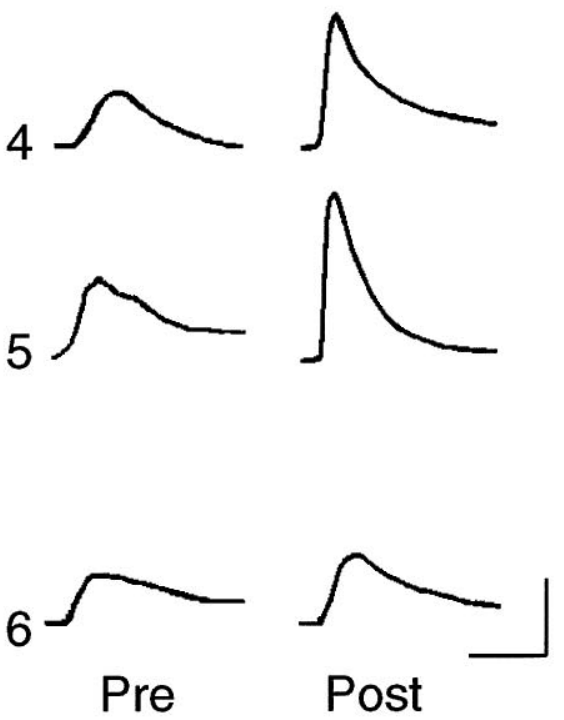

Post

Figure 4. Long-term facilitation of SN-L7 synapses with 5-HT is accompanied by an increase in glutamate response at zones with preexisting and new SN varicosities. $A$, Nomarski contrast image of proximal 300-350 $\mu \mathrm{m}$ portion of L7's axon. L7 cell body is just out of view at bottom. The numbers indicate the location of the sites of glutamate applications (1000 $\mu \mathrm{M}$ with 10 - to $15-\mu \mathrm{m}$-wide stream lasting $100 \mathrm{msec})$ both before and after treatment. The fine neurites of L7 extending adjacent to the axon are unchanged over the $24 \mathrm{hr}$ period and were used to relocate the zones for the second recording. Scale bar, $15 \mu \mathrm{m} . B, C$, Epifluorescent view of all SN neurites and varicosities (superimposition of three focal planes) in the same area as in $A$ interacting with L7 axons before $(B)$ and $24 \mathrm{hr}$ after $(C)$ treatment with 5-HT. EPSP amplitude increased from $18 \mathrm{mV}$ on day 4 to $30 \mathrm{mV}$ on day 5 . The arrows in $B$ point to varicosities that are no longer present on day 5 . The arrows in $C$ point to some of the new varicosities. Overall, there was a net change of 10 varicosities. $D$, Response to glutamate in each zone (zones 1-6) before (Pre) and $24 \mathrm{hr}$ after (Post) treatment with 5-HT. Note that the largest increases in glutamate response are in zones with preexisting or new SN varicosities (zones 3-5). Although the rate of rise for the individual responses in this preparation before treatment was somewhat slower than average, there were no overall differences between the control and 5-HT groups before treatment (see Results). The responses for the control cell illustrated in Figure 5 were obtained on the same day as those illustrated here with the same set of pipettes at each time point. Another zone distal to this region was not included. No change in response was observed in the most distal site along the L7 axon that had no SN varicosities. Calibration: vertical, $5 \mathrm{mV}$; horizontal, $200 \mathrm{msec}$.

solutions (Fig. 7). Unlike the co-cultures, there was no significant change evoked by 5-HT. Overall, the average amplitude of the responses in control L7 cells changed by $9.7 \pm 5.4 \%$ compared with $11.2 \pm 6.5 \%$ for responses evoked in L7 cells treated with 5-HT (Fig. $8 C$ ). These changes were not significantly different from the changes observed in the co-cultures treated with control solutions. Thus, long-term changes in SN-L7 connections with 5-HT are accompanied by an increase in glutamate sensitivity on the postsynaptic cell that is dependent on the presence of SN varicosities.

\section{DISCUSSION}

Our results indicate that the formation of new synaptic connections between central neurons of Aplysia in culture is accompanied by alterations in local glutamate sensitivity of the target cell. Glutamate evokes larger responses in motor cell L7 when applied to regions apposed to $\mathrm{SN}$ structures with transmitter release sites. This suggests that interactions with developing or mature presynaptic SN varicosities lead to expression of functional neurotransmitter receptors to specific patches of postsynaptic membrane. 

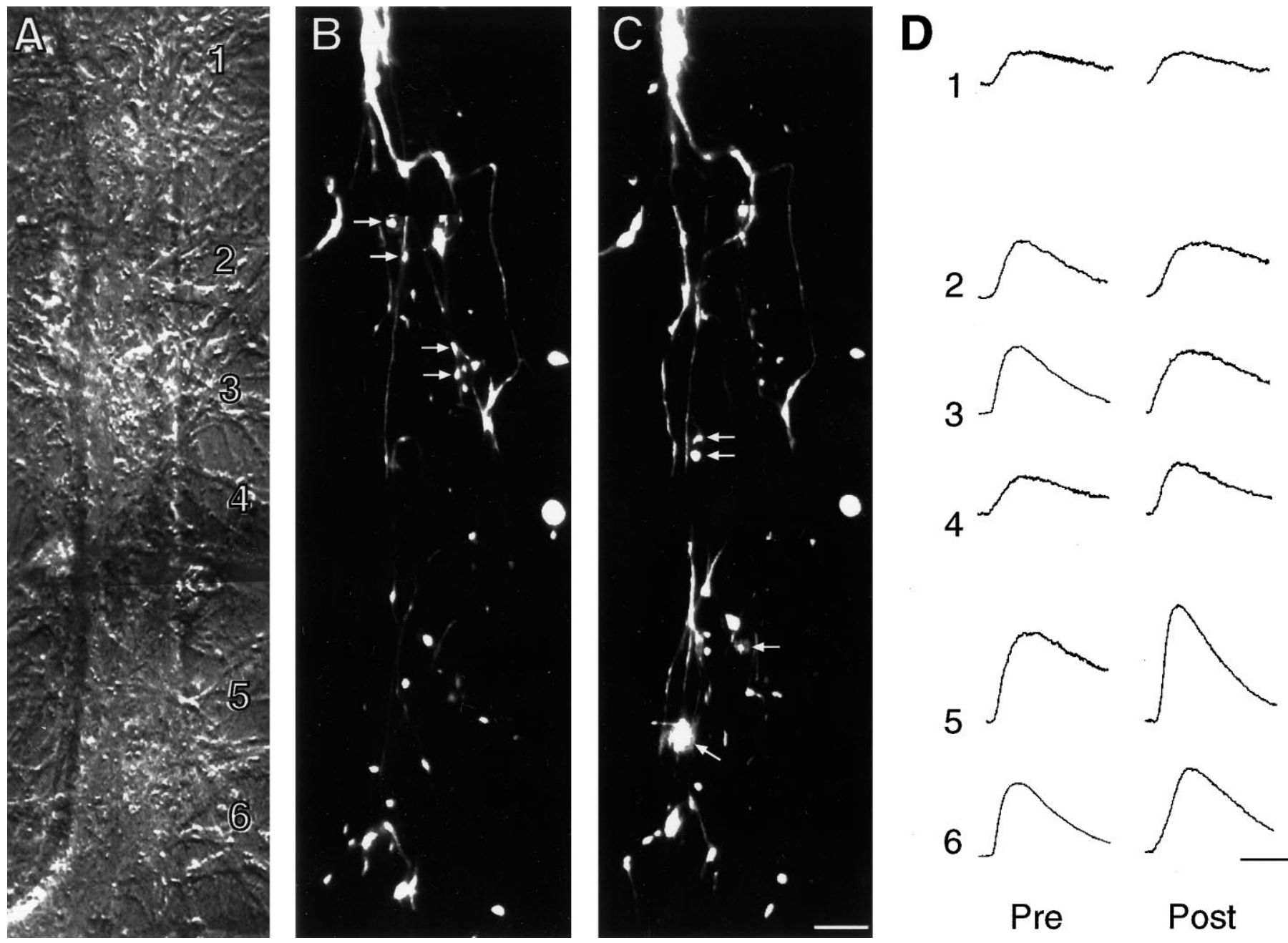

Figure 5. SN structure and glutamate responses before and after control treatment. $A$, Nomarski contrast view of proximal 300-350 $\mu \mathrm{m}$ portion of L7's axon. L7 cell body is just out of view at bottom. The numbers indicate the zones of glutamate applications (1000 $\mu \mathrm{M}$ with 10 - to $15-\mu \mathrm{m}$-wide streams lasting $100 \mathrm{msec}$ ) both before and after treatment. A more distal zone is not shown. Scale bar, $15 \mu \mathrm{m} . B, C$, Epifluorescent view of SN neurites and varicosities (superimposition of up to three focal planes) in the same area as in $A$ interacting with L7 axon before $(B)$ and $24 \mathrm{hr}$ after $(C)$ control treatment. EPSP amplitude changed from $20 \mathrm{mV}$ on day 4 to $22 \mathrm{mV}$ on day 5 . The arrows in $B$ point to some of the varicosities that are no longer present on day 5 . The arrows in $C$ point to some of the new varicosities. There was an overall net change of two SN varicosities contacting this portion of the L7 axon. $D$, Response to glutamate in each zone (zones 1-6) before (Pre) and $24 \mathrm{hr}$ after (Post) control treatment. Note little significant change in the amplitude or rate of rise of the responses to glutamate. Calibration: vertical, $5 \mathrm{mV}$; horizontal, $200 \mathrm{msec}$.

The development of this uneven distribution of functional receptors could contribute to the changes in synaptic efficacy that occur with new synapse formation during the first $4 \mathrm{~d}$ in culture (Zhu et al., 1994; Sun and Schacher, 1996). With new synapse formation associated with long-term facilitation evoked by 5-HT, interactions with an $\mathrm{SN}$ also appear to direct changes in the expression of functional glutamate receptors on $\mathrm{L} 7$ to sites with $\mathrm{SN}$ varicosities.

At the developing vertebrate and invertebrate neuromuscular junction, factors released by the presynaptic motor neuron growth cone and/or developing terminal influences both the synthesis of neurotransmitter receptors as well as their distribution (Falls et al., 1990; McMahan, 1990; Broadie and Bate, 1993a,b,c). A parallel mechanism may operate during the formation of synaptic connections in the CNS such that the expression of transmitter receptor subunits and targeted distribution of these receptors to appropriate sites are influenced by interaction with presynaptic cells (O'Brien and Fischbach, 1986a,b; Bekkers and Stevens, 1989; Craig et al., 1993, 1994; Liu and Tsien, 1995; Vogt et al., 1995; Ehlers et al., 1996). However, unlike the muscle cell target, which generally receives at most a few presynaptic inputs, central neurons receive inputs from many cells that release an array of neurotransmitters. Effective control of the receptor distribution may require not only cell-specific signaling (Craig et al., 1994, 1996), but additional mechanisms to specify and/or maintain the appropriate aggregation of functional receptors at sites associated with the corresponding presynaptic release sites (Ehlers et al., 1996).

With synapse formation between a single regenerating $\mathrm{SN}$ and motor cell L7, our data are consistent with the idea that interaction with presynaptic SN varicosities influences primarily the distribution of functional glutamate receptors and/or the targeted insertion of newly synthesized receptors. Adjacent regions of L7 that differed significantly in the number of $\mathrm{SN}$ varicosities also differed significantly in glutamate sensitivity. This raises the possibility that functional receptors aggregate at sites with varicosities at the expense of neighboring regions with few or no varicosities (see Fig. 3). This aggregation may arise via a mechanism involving the local release of factors such as glutamate itself, other secretory 

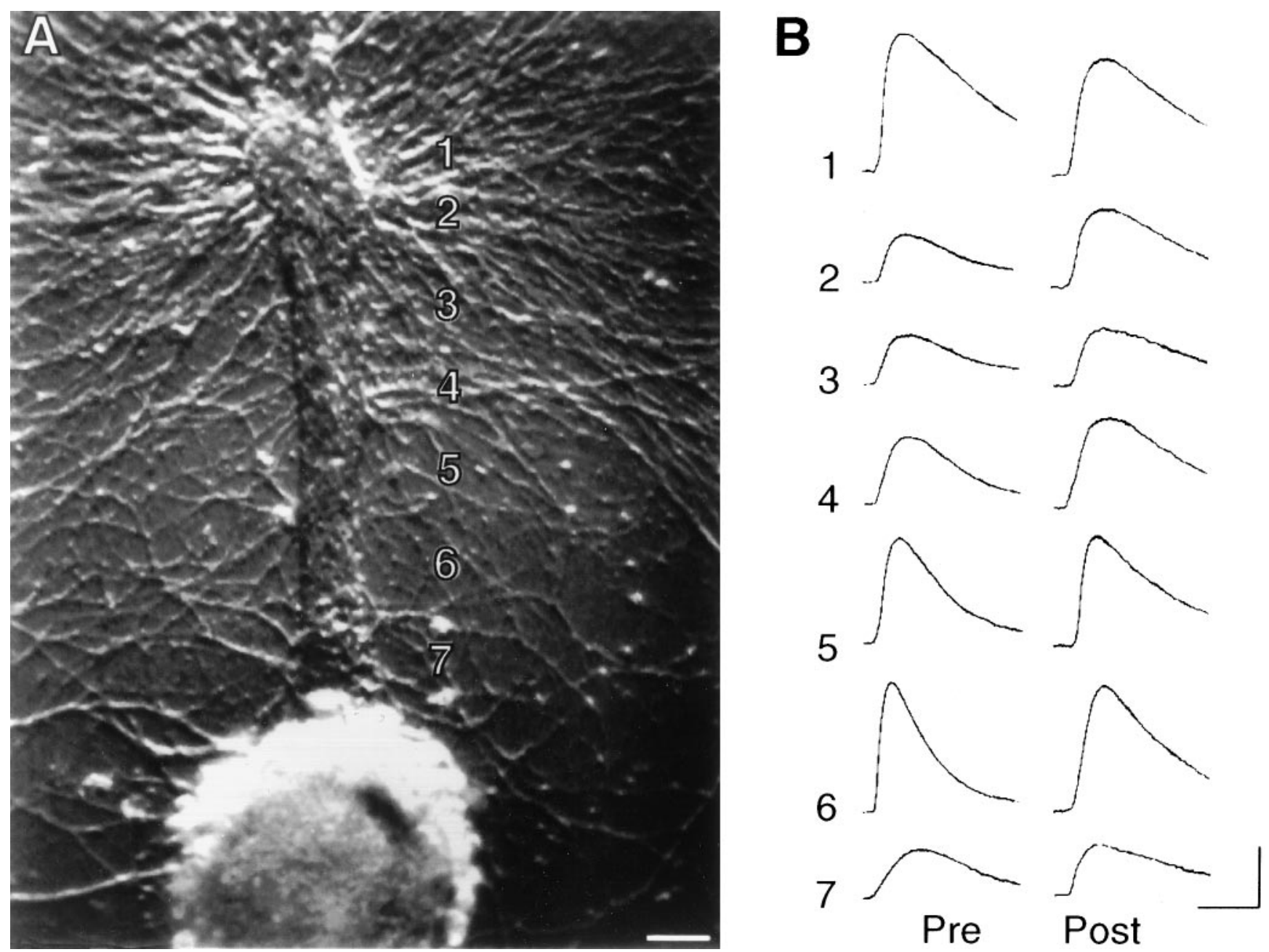

Figure 6. Long-term change in glutamate response with 5-HT is not expressed in the absence of an SN. $A$, Nomarski contrast view of L7 cell body and proximal axon. The numbers indicate the zones of glutamate application $(1000 \mu \mathrm{m}$ with 10 - to 15 - $\mu \mathrm{m}$-wide stream for $100 \mathrm{msec})$. Scale bar, $30 \mu \mathrm{m}$. $B$, Responses to glutamate applied to each zone before (Pre) and $24 \mathrm{hr}$ after (Post) treatment with 5-HT. Note that application of glutamate on zone 1, the axon stump, evoked a larger response than on the neighboring zone. In addition, glutamate responses in zones $\sim 50 \mu \mathrm{m}$ of the L7 cell body were typically smaller than those at $\sim 100 \mu \mathrm{m}$ (zone 7, for example). On average, each application of glutamate evoked a $6.8 \pm 0.9 \mathrm{mV}$ response per L7 on day 4 before treatment. Calibration: vertical, $5 \mathrm{mV}$; horizontal, $200 \mathrm{msec}$.

constituents in SN synaptic terminals such as the neuropeptide sensorin (Brunet et al., 1991; Santarelli et al., 1996), or other as yet unidentified molecules (Sandrock et al., 1995). These factors bind to existing receptors that may influence the synthesis of cytoplasmic constituents of the postsynaptic cell required for receptor aggregation (Kornau et al., 1995; Gillespie et al., 1996; Muller et al., 1996). In addition, interaction between other cell surface molecules expressed on the cells may lead to downstream changes in the respective organization of the postsynaptic structures needed for functional receptor aggregation. Our earlier studies suggest that the distribution of apCAM, an NCAM-like cell adhesion molecule, influences where new synapses will form both during regeneration and after treatment with 5-HT (Zhu et al., 1994, 1995). The receptor-ligand interactions between cell adhesion molecules can alter the activity of second messenger systems (Atashi et al., 1992; Doherty and Walsh, 1992). Changes in the activity of these second messenger systems can influence the expression and subsequent distribution of functional glutamate receptors or modulate the properties of the receptors via protein modification or phosphorylation (Greengard et al., 1991; Raymond et al., 1993; Ehlers et al., 1995).
Although one interpretation of our results is that synaptic interaction affects the distribution of functional receptors without changing the overall level of functional receptors expressed on L7, we cannot yet rule out the possibility that interaction with an SN alters the relative expression of particular glutamate receptor subtypes or subunits. The postsynaptic targets of the SNs, including L7, express at least two subtypes with properties that are characteristic of the vertebrate NMDA and AMPA glutamate receptors (Dale and Kandel, 1993; Lin and Glanzman, 1994). Interaction with an $\mathrm{SN}$ may alter the relative ratio of expression for glutamate receptor subtypes leading to increased glutamate responses at synaptic sites (Ehlers et al., 1995; Isaac et al., 1995). In future experiments, with the development of appropriate molecular probes and the application of available pharmacological agents that can bind specific glutamate receptors in Aplysia, we will be in a position to examine the distribution of the specific receptor subtypes on $\mathrm{L} 7$ in both the presence and the absence of an $\mathrm{SN}$ and at sites with or without $\mathrm{SN}$ varicosities.

Applications of 5-HT, a transmitter critical for behavioral and cellular plasticity in Aplysia (Glanzman et al., 1989b) and one that evokes long-term functional and structural plasticity of SN-L7 

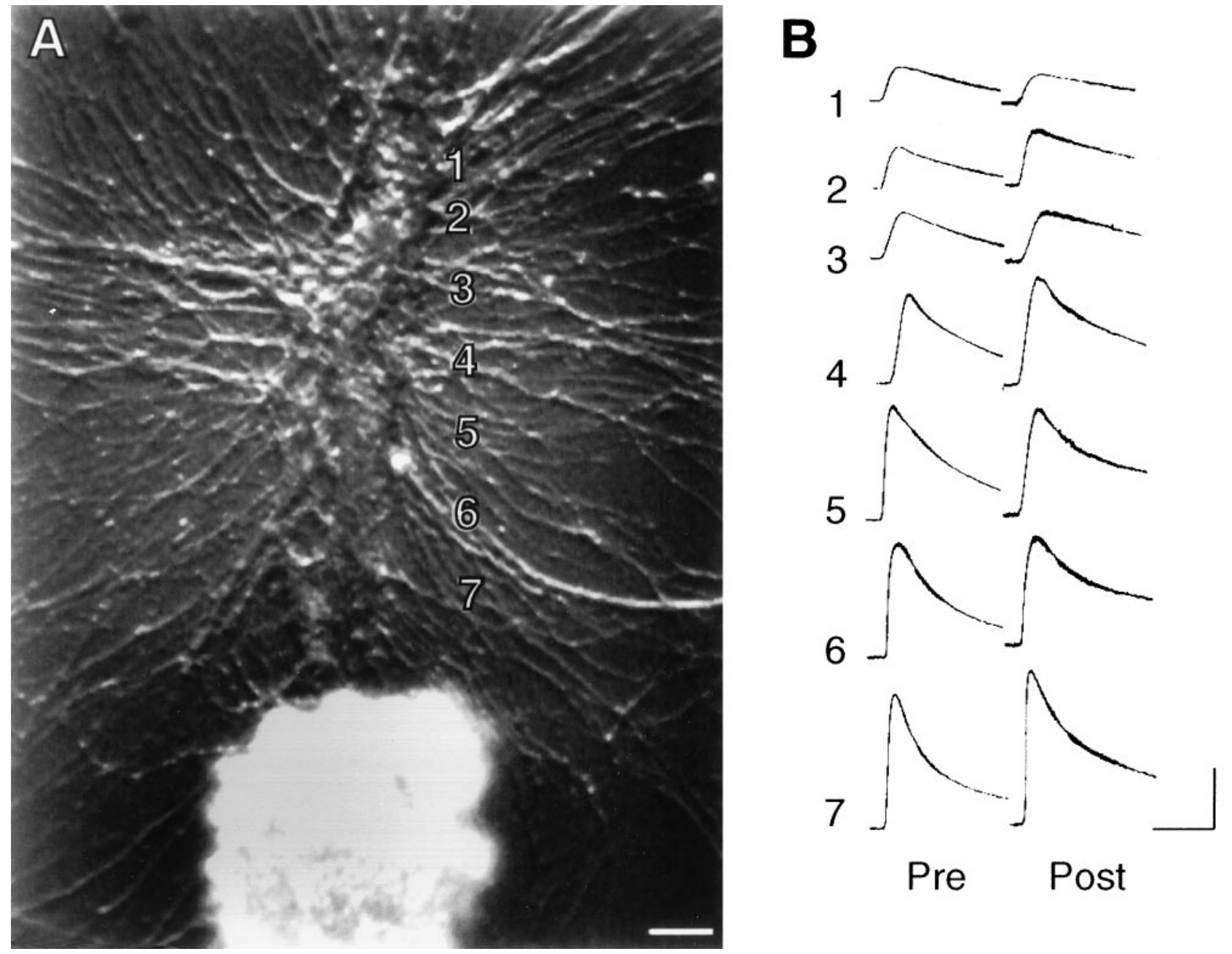

Figure 7. Glutamate responses in L7 cultured alone are unchanged $24 \mathrm{hr}$ after control treatment. $A$, Nomarski contrast view of L7 cell body and proximal axon. The numbers indicate the zones of glutamate application (see Fig. 6). Scale bar, $30 \mu \mathrm{m}$. B, Responses to glutamate applied to each zone before (Pre) and $24 \mathrm{hr}$ after (Post) control treatment. The overall response for each zone changed little. On average, each application of glutamate evoked a $6.6 \pm$ $1.1 \mathrm{mV}$ response per $\mathrm{L} 7$ on day 4 before treatment. Calibration: vertical, $5 \mathrm{mV}$; horizontal, $200 \mathrm{msec}$.

connections (Montarolo et al., 1986; Glanzman et al., 1990), also evoke site-specific increases in glutamate sensitivity that correlate with the presence of both preexisiting and new SN varicosities. Because the increases at these sites were not accompanied by a significant decline in glutamate sensitivity at sites with few or no varicosities, the results suggest that 5 -HT evokes an increase in functional glutamate receptors expressed on the surface of L7 (Trudeau and Castellucci, 1995) that are targeted to synaptic sites. This would be consistent with the idea that additional functional glutamate receptors are expressed at new release sites that may form in both new SN varicosities (Glanzman et al., 1990) as well as in preexisting varicosities. Existing varicosities may now contain larger active zones (Bailey and Chen, 1983, 1988b) and/or may have formed additional active zones (Wojtowicz et al., 1994; Stewart et al., 1996) after treatment with 5-HT. These changes in distribution of glutamate receptors could contribute to the 5-HTinduced increase in quantal number without necessarily causing a change in quantal size (Dale et al., 1988).

The long-term change in glutamate sensitivity in L7 evoked by 5-HT required the presence of a presynaptic SN. One interpretation of these results is that the changes in L7 are evoked by the actions of 5-HT first on the SN to initiate the growth and forma- tion of new varicosities and active zones. These changes lead to the release of presynaptic factors or the activation of other cellcell interactions that influence functional receptor distribution on L7 (see above). Alternatively, the changes in glutamate receptors on L7 may be evoked by the actions of 5-HT binding to receptors on L7 itself. Interaction with an SN might lead to the expression of the appropriate 5-HT receptors on L7 that trigger these longterm changes. Interactions between presynaptic and postsynaptic neurons can influence the level of expression of particular types of neurotransmitter receptors and the signal transduction pathways that are activated by receptor-ligand interaction (Drapeau et al., 1995; Sun and Schacher, 1996). Thus, in the presence of an SN, L7 may express appropriate levels of a 5-HT receptor that, with repeated applications of 5-HT, trigger second messengermediated long-lasting changes in the properties of the glutamate receptors (Blackstone et al., 1994; Roche et al., 1994) or increases in the overall expression of glutamate receptors. Using this in vitro preparation, it will be possible to test whether the changes in postsynaptic glutamate sensitivity is affected primarily by the long-term actions of 5-HT on the presynaptic SN or the postsynaptic L7. In future experiments, we will examine whether longterm changes in glutamate sensitivity accompany long-term facil- 

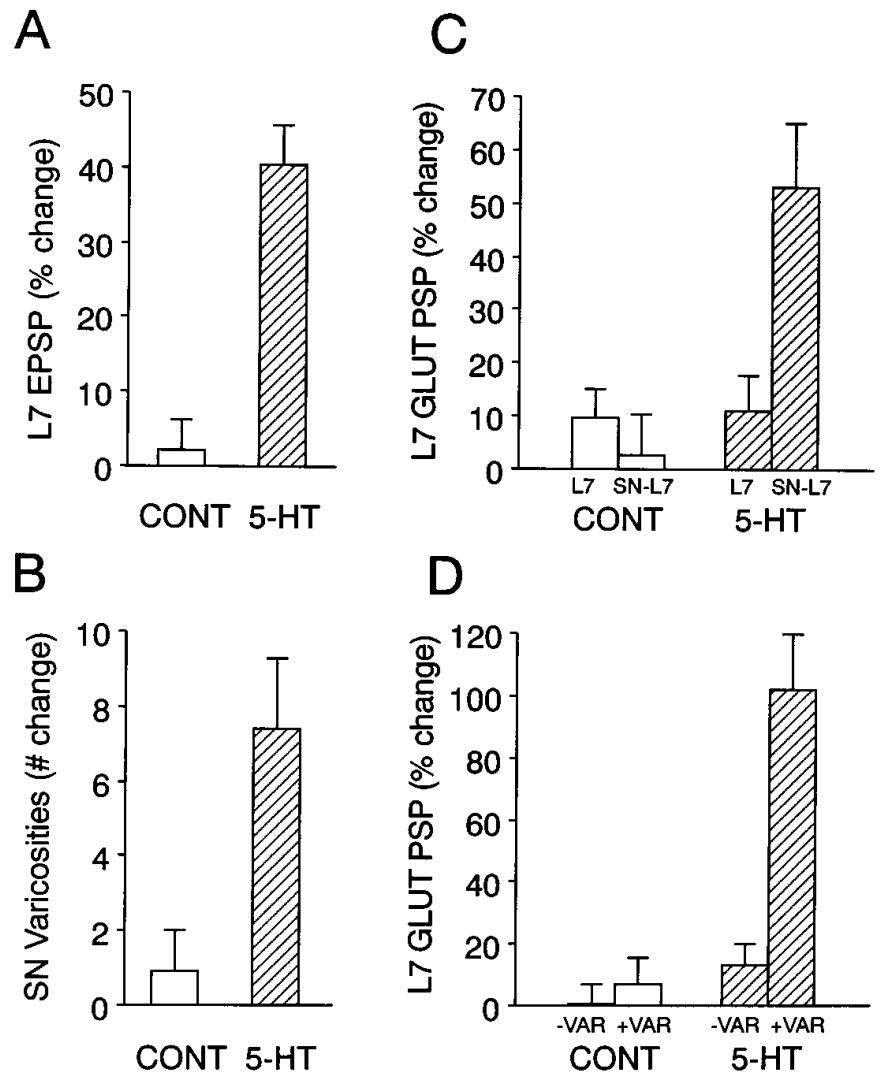

Figure 8. Summary of the long-term changes evoked by 5 -HT in the presence and absence of SNs. $A$, Long-term increase in synaptic efficacy evoked by 5-HT in SN-L7 cocultures. The height of each bar is the mean + SEM change in the amplitude of the EPSP evoked in L7 $24 \mathrm{hr}$ after treatment. There was no significant difference $(p>0.4)$ in the average amplitude of the initial EPSP for each group $(21.4 \pm 2.7 \mathrm{mV}$ for controls and $23.8 \pm 3.8 \mathrm{mV}$ for 5-HT). 5-HT evoked a significant change compared with control $(t=5.681 ; p<0.001) . B$, Change in the number of SN varicosities contacting L7's axon $24 \mathrm{hr}$ after treatment. There was no significant difference between the two groups in the number of SN varicosities in contact with the proximal segment of L7's axon $(25.9 \pm 5.8$ varicosities for controls and $23.5 \pm 4.7$ varicosities for 5 -HT). 5 -HT evoked a significant change compared with control $(t=4.509 ; p<0.001)$. $C$, Glutamate responses are enhanced by $5-\mathrm{HT}$ in $\mathrm{SN}-\mathrm{L} 7$ cultures, but not in L7 alone cultures. The height of each bar is the mean + SEM percent change in the response to glutamate per culture $(n=10$ for each condition). The change in each culture was calculated as the average change in response for all zones (seven zones per culture). A two-factor ANOVA (treatment and presence of an $\mathrm{SN}$ ) indicated an overall significant change in glutamate response $(\mathrm{df}=1,18 ; F=8.578 ; p<0.01)$. The only significant change was obtained when 5 -HT was applied to the cocultures. The change in this group was significant compared with 5-HT applied to L7 alone $(F=4.248 ; p<0.01)$, control treatment of the cocultures $(F=6.117 ; p<0.01)$, and control treatment to L7 alone $(F=$ $4.557 ; p<0.01)$. $D$, Glutamate responses are enhanced by 5 -HT primarily at sites with SN varicosities. The height of each bar is the mean + SEM percent change in glutamate response per SN-L7 culture at sites with ( $+V A R$ indicates zones with three or more varicosities) or without ( $-V A R$ indicates zones with two or fewer varicosities) SN varicosities. A twofactor ANOVA (treatment and presence of SN varicosities) indicated an overall significant change in glutamate response $(\mathrm{df}=1,18 ; F=31.815$; $p<0.001)$. The only significant change was obtained at sites with $\mathrm{SN}$ varicosities after treatment with $5-\mathrm{HT}$. The change at $\mathrm{SN}$ varicosities after 5-HT treatment was significant compared with the change at sites without varicosities after 5-HT $(F=10.609 ; p<0.01)$, at sites with varicosities after control treatment $(F=12.163 ; p<0.01)$, and at sites without varicosities after control treatment $(F=13.931 ; p<0.01)$. itation of SN connections that are evoked with region- or cellspecific manipulations, such as intracellular injection of cAMP into SNs (Schacher et al., 1993) or applications of 5-HT selectively to the cell body of the SN (Clark and Kandel, 1993; Emptage and Carew, 1993; Sun and Schacher, 1996).

\section{REFERENCES}

Atashi JR, Klinz SG, Ingraham CA, Matten WT, Schachner M, Maness PF (1992) Neural cell adhesion molecules modulate tyrosine phosphorylation of tubulin in nerve growth cone membranes. Neuron 8:831-842.

Bailey CH, Chen M (1983) Morphological basis of long-term habituation and sensitization in Aplysia. Science 220:91-93.

Bailey CH, Chen M (1988a) Long-term memory in Aplysia modulates the total number of varicosities of single identified neurons. Proc Natl Acad Sci USA 85:2372-2377.

Bailey CH, Chen M (1988b) Long-term sensitization in Aplysia increases the number of presynaptic contacts onto the identified gill motor neuron L7. Proc Natl Acad Sci USA 85:9356-9359.

Bailey CH, Kander ER (1993) Structural changes accompany memory storage. Annu Rev Physiol 55:397-426.

Bank M, Schacher S (1992) Segregation of presynaptic inputs on an identified target neuron in vitro: structural remodeling visualized over time. J Neurosci 12:2960-2972.

Bekkers JM, Stevens CF (1989) NMDA and non-NMDA receptors are co-localized at individual excitatory synapses in cultured rat hippocampus. Nature 341:230-233.

Blackstone C, Murphy TH, Moss SJ, Baraban JM, Huganir RL (1994) Cyclic AMP and synaptic activity-dependent phosphorylation of AMPA-preferring glutamate receptors. J Neurosci 14:7585-7593.

Broadie K, Bate M (1993a) Activity-dependent development of the neuromuscular synapse during Drosophila embryogenesis. Neuron 1993:607-619.

Broadie K, Bate M (1993b) Development of the embryonic neuromuscular synapse of Drosophila melanogaster. J Neurosci 13:144-166.

Broadie K, Bate M (1993c) Innervation directs receptor synthesis and localization in Drosophila embryo synaptogenesis. Nature 361:350-353.

Brunet J-F, Shapiro E, Foster SA, Kandel ER, Iino Y (1991) Identification of a peptide specific for Aplysia sensory neurons by PCR-based differential screening. Science 252:856-859.

Castellucci VF, Carew TJ, Kandel ER (1978) Cellular analysis of longterm habituation of the gill-withdrawal reflex of Aplysia californica. Science 202:1306-1308.

Clark GA, Kandel ER (1993) Induction of long-term facilitation in Aplysia sensory neurons by local application of serotonin to remote synapses. Proc Natl Acad Sci USA 90:11411-11415.

Craig AM, Blackstone CD, Huganir RL, Banker G (1993) The distribution of glutamate receptors in cultured rat hippocampal neurons: postsynaptic clustering of AMPA-selective subunits. Neuron 10:1055-1068.

Craig AM, Blackstone CD, Huganir RL, Banker G (1994) Selective clustering of glutamate and gamma-aminobutyric acid receptors opposite terminals releasing the corresponding neurotransmitters. Proc Natl Acad Sci USA 91:12373-12377.

Craig AM, Banker G, Chang W, McGrath ME, Serpinskaya AS (1996) Clustering of gephyrin at GABAergic but not glutamatergic synapses in cultured rat hippocampal neurons. J Neurosci 16:3166-3177.

Dale N, Kandel ER (1993) L-glutamate may be the fast excitatory transmitter of Aplysia sensory neurons. Proc Natl Acad Sci USA 90:7163-7167.

Dale N, Schacher S, Kandel ER (1988) Long-term facilitation in Aplysia involves increase in transmitter release. Science 239:282-285.

Davies SN, Lester RAJ, Reymann KG, Collingridge GL (1989) Temporally distinct pre- and postsynaptic mechanisms maintain long-term potentiation. Nature 338:500-503.

Doherty P, Walsh FS (1992) Cell adhesion molecules, second messengers and axonal growth. Curr Opin Neurobiol 2:595-601.

Drapeau P, Catarsi S, Merz DC (1995) Signaling synapse formation between identified neurons. J Physiol (Paris) 89:115-123.

Edwards FA (1995) LTP-a structural model to explain the inconsistencies. Trends Neurosci 18:250-255.

Ehlers MD, Tingley WG, Huganir RL (1995) Regulated subcellular distribution of the NR1 subunit of the NMDA receptor. Science 269:1734-1737. 
Ehlers MD, Mammen AL, Lau LF, Huganir RL (1996) Synaptic targeting of glutamate receptors. Curr Opin Cell Biol 8:484-489.

Emptage NJ, Carew TJ (1993) Long-term synaptic facilitation in the absence of short-term facilitation in Aplysia neurons. Science 262:253-256.

Falls DL, Harris DA, Johnson FA, Morgan MM, Corfas G, Fischbach GD (1990) ARIA: a protein that may regulate the accumulation of acetylcholine receptors at developing chick neuromuscular junction. Cold Spring Harb Symp Quant Biol 50:397-406.

Frost WN, Castellucci VF, Hawkins RD, Kandel ER (1985) Monosynaptic connections made by the sensory neurons of the gill- and siphonwithdrawal reflex in Aplysia participate in the storage of long-term memory for sensitization. Proc Natl Acad Sci USA 82:8266-8269.

Gapon S, Kupfermann I (1996) Evidence for transmitter similarity of two classes of mechanoreceptor neurons in the cerebral ganglion of Aplysia. Neurosci Lett 205:157-160.

Gillespie SK, Balasubramanian S, Fung ET, Huganir RL (1996) Rapsyn clusters and activates the synapse-specific receptor tyrosine kinase MuSK. Neuron 16:953-962.

Glanzman DL (1995) Postsynaptic regulation of the development and long-term plasticity of Aplysia sensorimotor synapses in cell culture. J Neurobiol 25:666-693.

Glanzman DL, Kandel ER, Schacher S (1989a) Identified target motor neuron regulates neurite outgrowth and synapse formation of Aplysia sensory neurons in vitro. Neuron 3:441-450.

Glanzman DL, Mackey SL, Hawkins RD, Dyke AM, Lloyd PE, Kandel ER (1989b) Depletion of serotonin in the nervous system of Aplysia reduces the behavioral enhancement of gill withdrawal as well as the heterosynaptic facilitation produced by tail shock. J Neurosci 9:4200-4213.

Glanzman DL, Kandel ER, Schacher S (1990) Target-dependent structural changes accompanying long-term synaptic facilitation in Aplysia neurons. Science 249:799-802.

Greengard P, Jen J, Nairn AC, Stevens CF (1991) Enhancement of the glutamate response by cAMP-dependent protein kinase in hippocampal neurons. Science 253:1135-1138.

Hall ZW, Sanes JR (1993) Synaptic structure and development: the neuromuscular junction. Cell 72:99-121.

Hawver DB, Schacher S (1993) Selective fasciculation as a mechanism for the formation of specific chemical connections between Aplysia neurons in vitro. J Neurobiol 24:368-383.

Isaac JTR, Nicholl RA, Malenka RC (1995) Evidence for silent synapses: implication for the expression of LTP. Neuron 15:427-434.

Jessell TM, Siegel RE, Fischbach GD (1979) Induction of acetylcholine receptors on cultured skeletal muscle by a factor extracted from brain and spinal cord. Proc Natl Acad Sci USA 76:5397-5401.

Kornau HC, Schenker LT, Kennedy MB, Seeburg PH (1995) Domain interaction between NMDA receptor subunits and the postsynaptic density protein PSD-95. Science 269:1737-1740.

Lin XY, Glanzman DL (1994) Hebbian induction of long-term potentiation of Aplysia sensorimotor synapses: partial requirement for activation of an NMDA-related receptor. Proc R Soc Lond [Biol] 255:215-221.

Liu G, Tsien RW (1995) Properties of synaptic transmission at single hippocampal synaptic boutons. Nature 375:404-408.

Lynch G, Baudry M (1984) The biochemistry of memory: a new and specific hypothesis. Science 224:1057-1063.

Maren S, Tocco G, Standley S, Baudry M, Thompson RF (1993) Postsynaptic factors in the expression of long-term potentiation (LTP): increased glutamate receptor binding following LTP induction in vivo. Proc Natl Acad Sci USA 90:9654-9658.

McMahan UJ (1990) The agrin hypothesis. Cold Spring Harb Symp Quant Biol 55:407-418.

Montarolo PG, Goelet P, Castellucci VF, Morgan J, Kandel ER, Schacher S (1986) A critical time window for macromolecular synthesis in longterm heterosynaptic facilitation in Aplysia. Science 234:1249-1254.

Muller BM, Kistner U, Kindler S, Chung WJ, Kuhlendahl S, Fenster SD, Lau LF, Veh RW, Huganir RL, Gundelfinger ED, Garner CC (1996) SAP102, a novel postsynaptic protein that interacts with NMDA receptor complexes in vivo. Neuron 17:255-265.
O’Brien RJ, Fischbach GD (1986a) Characterization of excitatory amino acid receptors expressed by embryonic chick motoneurons in vitro. J Neurosci 6:3275-3283.

O'Brien RJ, Fischbach GD (1986b) Modulation of embryonic chick motoneuron glutamate sensitivity by interneurons and agonists. J Neurosci 6:3290-3296.

Raymond LA, Blackstone CD, Huganir RL (1993) Phosphorylation and modulation of recombinant GluR6 glutamate receptors by cAMPdependent protein kinase. Nature 361:637-641.

Rayport SG, Schacher S (1986) Synaptic plasticity in vitro: cell culture of identified Aplysia neurons mediating short-term habituation and sensitization. J Neurosci 6:759-763.

Roche KW, Tingley WG, Huganir RL (1994) Glutamate receptor phosphorylation and synaptic plasticity. Curr Opin Neurobiol 4:383-388.

Sandrock Jr AW, Goodearl AD, Yin QW, Chang D, Fischbach GD (1995) ARIA is concentrated in nerve terminals at neuromuscular junctions and at other synapses. J Neurosci 15:6124-6136.

Santarelli L, Montarolo PG, Schacher S (1996) Neuropeptide localization in varicosities of Aplysia sensory neurons is regulated by target and neuromodulators evoking long-term synaptic plasticity. J Neurobiol 31:297-308.

Schacher S (1985) Differential synapse formation and neuritic outgrowth at two branches of the metacerebral cell of Aplysia in dissociated cell culture. J Neurosci 5:2028-2034.

Schacher S, Montarolo PG (1991) Target-dependent structural changes in sensory neurons of Aplysia accompany long-term heterosynaptic inhibition. Neuron 6:679-690.

Schacher S, Proshansky E (1983) Neurite regeneration by Aplysia neurons is dissociated cell culture: modulation by Aplysia hemolymph and the presence of the initial axon segment. J Neurosci 3:2403-2413.

Schacher S, Glanzman DL, Barzilai A, Dash P, Grant SGN, Keller F, Mayford M, Kandel ER (1990) Long-term facilitation in Aplysia: persistent phosphorylation and structural changes. Cold Spring Harb Symp Quant Biol 55:187-202.

Schacher S, Kandel ER, Montarolo PG (1993) cAMP and arachidonic acid simulate long-term structural and functional changes produced by neurotransmitters in Aplysia sensory neurons. Neuron 10:1079-1088.

Stewart BA, Schuster CM, Goodman CS, Atwood HL (1996) Homeostasis of synaptic transmission in Drosophila with genetically altered nerve terminal morphology. J Neurosci 16:3877-3886.

Sun Z-Y, Schacher S (1996) Development of short-term heterosynaptic facilitation at Aplysia sensorimotor synapses in vitro is accompanied by changes in the functional expression of presynaptic serotonin receptors. J Neurophysiol 76:2250-2261.

Sun Z-Y, Kauderer B, Schacher S (1996) Differential distribution of functional receptors for neuromodulators evoking short-term heterosynaptic plasticity in Aplysia sensory neurons. J Neurosci 16:7540-7549.

Trudeau LE, Castellucci VF (1993) Excitatory amino acid neurotransmission at sensory-motor and interneuronal synapses of Aplysia californica. J Neurophysiol 70:1221-1230.

Trudeau LE, Castellucci VF (1995) Postsynaptic modifications in longterm facilitation in Aplysia: upregulation of excitatory amino acid receptors. J Neurosci 15:1275-1284.

Vogt K, Luscher HR, Streit J (1995) Analysis of synaptic transmission at single identified boutons on rat spinal neurons in culture. Eur J Physiol 430:1022-1028.

Wojtowicz JM, Marin L, Atwood HL (1994) Activity-induced changes in synaptic release sites at the crayfish neuromuscular junction. J Neurosci 14:3688-3703.

Wu F, Friedman L, Schacher S (1995) Transient versus persistent functional and structural changes associated with facilitation of Aplysia sensorimotor synapses are second messenger dependent. J Neurosci 15:7517-7527.

Zhu H, Wu F, Schacher S (1994) Aplysia cell adhesion molecules and serotonin regulate sensory cell-motor cell interactions during early stages of synapse formation in vitro. J Neurosci 14:6886-6900.

Zhu H, Wu F, Schacher S (1995) Changes in expression and distribution of Aplysia cell adhesion molecules can influence synapse formation and elimination in vitro. J Neurosci 15:4173-4183. 